\title{
HANS SCHÄFER
}

Probleme einer Neugliederung des Bundesgebietes 


\section{SCHRIFTENREIHE DER JURISTISCHEN GESELLSCHAFT e.V. BERLIN}

Heft 12

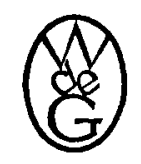

Berlin 1963

\section{WALTER DE GRUYTER \& CO.}

vormals G. J. Göschen'sche Verlagshandlung · J.Guttentag, Verlagabuchhandlang Georg Reimer - Karl J. Trübner - Veit \& Comp. 


\title{
Probleme einer Neugliederung des Bundesgebietes
}

\author{
Von \\ Dr. Hans Schäfer \\ Staatssekretär im Bundesministerium des Innern, Bonn
}

\author{
Vortrag \\ gehalten vor der \\ Berliner Juristischen Gesellschaft \\ am 1. Februar 1963
}

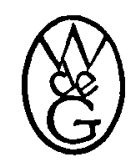

Berlin 1963

\section{WALTER DE GRUYTER \& CO.}

vormals G. J. Göschen'sche Verlagshandlung · J.Guttentag, Verlagsbuchhandlung Georg Reimer - Karl J. Trübner - Veit \& Comp. 
Archiv $+N_{r}, 2727635$

Satz und Druck: 8 Saladrudk, Berlin 65

Alle Rechte, einschlieBlich des Rechtes der Herstellung von Fotokopien und Mikrofilmen, rorbehalten 